\title{
On the Development of College English Teachers in Local Minzu Colleges
}

\author{
Shan Ronglin \\ School of Foreign Languages \\ Sichuan Minzu College \\ Kangding, Sichuan 626001, China
}

\begin{abstract}
The national medium and long-term education reform and development planning outlines the need to build a high-quality teaching team. The teachers are the base of education plan. Only if there are good teachers, can there be a good education. At the same time, it is necessary to enhance the sense of responsibility and mission of teachers when te aching and educating people. The teacher should educate the students with his personality charm and academic charm, being the instructor and guide for the healthy growth of the students [1]. In the face of the new situation, college English teachers in local Minzu colleges must profoundly understand their mission and challenges, continuously improve their professionalism and teaching level, take positive measures to develop themselves, and absorb and inherit multiculturalism, thus to be on better service to higher education in ethnic areas and even the society.
\end{abstract}

Keywords-local Minzu college; college English Teachers; development; strategy

\section{INTRODUCTION}

The 3rd National High School Forum on Foreign Language Education Reform and Development was grandly opened in Beijing from March 24th to 25th, 2018. In his speech, Professor Wang Dinghua, Secretary of the Party Committee of Beijing Foreign Studies University, gave a high-level explanation of the connotation of this conference theme with regards to New Era, New Talent and New Strategy: the development of socialism with Chinese characteristics entered a new era, the main contradictions of Chinese society have changed, and higher education is required to pay more attention to the improvement of education equity and education quality, with a focus on connotative development. The promulgation of the newly amended Constitution and the further development of the national foreign strategy provide an institutional basis and a broad development opportunity and space for the reform and development of higher education. At the same time, the high-quality development of basic education in New Era, the breakthrough progress of brother universities, and the rapid development of artificial intelligence have also brought new challenges to higher education.

In the College English Teacher Team Building and Interactive Development Seminar, Liu Guiqin, former deputy director of the Higher Education Department of the Ministry of Education, pointed out in his report that "strengthening the

This article is the phase results of the application model course project College English (project number: sfkc201748) and the school-level education and teaching reform research project College English Curriculum Practice Education System Construction and Exploration Research (project number: 2017xjjg21) by Academic Affairs Office of Sichuan Nationalities University in 2017 construction of the teaching staff is the key to improving the quality of higher education. To build a high-level teaching team, we should focus on strengthening the moral construction of teachers first, take the primary to improving the teaching ability of teachers, and based on improving the level of subject research of teachers. Learning from the advanced experience at home and abroad and setting up a college teacher education development center is to be the benefit of teacher's development and team building.'’[2]. Due to some historical and natural reasons, the development of ethnic education still faces some special difficulties and obvious problems. The overall development level is still far behind the national average. Therefore, college English teachers in local ethnic colleges should always bear in mind their role and mission, deeply analyzing themselves. In the aspects of teachers' morality, professionalism, education and teaching skills, and scientific research, the teachers should also strive to improve themselves, do self-development, and keep pace with the era. In the education and teaching work, teachers are responsible to internalize Chinese traditional culture into the core literacy of students through appropriate methods, actively guide students to establish a global vision, enhance their humanistic feelings, and help them to develop a good quality of lifelong learning. Comprehensively improve the ability of that the national education and subject research can be on serve of national education development so that it will meet the expectations of college teachers of the ethnic society and let them face the challenges in New Era.

\section{The Roles, Opportunities AND Challenges of COLlege English TeACHERS}

\section{A. The roles of college English teachers}

Most college English teachers in undergraduate colleges pay attention to the reform of college English teaching and want to learn its content and form through various channels then carry out a transformation of traditional ideas and concepts, because the positive change in thought is a deep-level reform, which is of great significance for instructing teachers in teaching practice. College English Course Guide clearly states: "University foreign language education is an important part of higher education in China, and it is important to promote the coordinated development of college students' knowledge, ability and comprehensive quality. College English as the main content of university foreign language education is a compulsory public foundation course for most non-English 
majors in the undergraduate education stage and plays an irreplaceable role in personnel training." College English teachers recognize the need to provide opportunities for students to communicate and interact with teachers in teaching. They will conduct metacognitive ability guidance for students in a targeted manner, train them for metacognitive strategies and enhance their metacognitive ability, thus cultivating the students' independent learning ability, implementing teacherled and student-centered teaching concept, changing the convention of teaching students the knowledge to teaching students the methods and ideas, and laying a stable foundation for their lifelong learning [3]. The role of the teacher has become the planner, organizer, participant and the guide of the students' learning. At the same time, the college English teachers should read more English-related professional books, participate in more academic conferences, and communicate with more teachers at the same level to learn the latest research results of the discipline and become a researcher on topics related to college English courses.

\section{B. Opportunities for College English Teachers}

The reform of college English teaching brings rare opportunities for teachers. The fourth point of view of the teaching management part in Teaching Requirements for College English Courses promulgated by the Ministry of Education states: "We are supposed to improve teacher training system. Teacher quality is the key to improving teaching quality, and the key to the university English course's construction and development. Schools should build a faculty with reasonable composition ratio in age, academic qualifications and professional titles, strengthen the training and cultivating of teachers, encourage teachers to actively carry out teaching research around the improvement of teaching quality, and create conditions to carry out various forms of teaching and research according to local conditions and promote to carry out fruitful cooperation in teaching and research work, so that they can adapt to the new teaching mode as soon as possible. At the same time, academic leaves and advanced studies should be appropriately arranged for the teachers to promote their continuous improvement of academic level and teaching methods."[4] This means that the Ministry of Education attaches great importance to the personal development of college English teachers, and all universities should implement them. College English teachers will face more development opportunities and will have the chance to participate in various training and academic conferences to enhance their educational concepts, professionalism and teaching methods.

\section{Challenges of College English Teachers}

There is reform, there is development. The reform of college English teaching is the trend of the era. This in-depth reform makes college English teachers must think deeply about the college English teaching related the new trends and reflect on their own teaching methods and teaching ideas. This kind of thinking and the subsequent changes in the teaching methods involved in the reform of college English teaching prompt teachers to update their teaching concepts and enrich their professional knowledge [5]. Mastering modern educational technology and other related actions will certainly promote the improvement of teachers' quality. Along with the progress of teaching reform, a series of more cutting-edge and advancing college English textbooks have emerged, of which the content is richer, the language is more vivid, and the combination of materials and era is more closely, which will put forward higher requirements on teachers' language ability and teaching ability. The importance of teachers' classroom teaching practice has become increasingly prominent. While teachers teach students knowledge, it is more important to develop students' thinking ability in class, because speculative ability is a crucial inquiry tool. It is a liberating force in education, and speculative ability is a universal self-correcting phenomenon between humans. An ideal thinker with speculative ability is accustomed to be diligent, knowledgeable, rational, openminded, flexible, fair in making evaluations, honest in the face of personal prejudice, cautious in making decision and willing to reconsider it, clear-minded when facing problems, and capable to consistently explore the question and results as accurate as possible if conditions permit. Therefore, cultivating thinkers with speculative ability means fighting for this ideal, which is exactly the foundation of a rational and democratic society [6]. And it is also the unshirkable responsibility of college English teachers.

\section{The KNOWLEDge AND ABILITy StRUCture OF College English TeAchers}

\section{A. The Status Quo of English Teachers in Local Ethnic Colleges}

The college English teachers' qualification in various ethnic colleges are uneven, but they are all undertaking almost the same college English teaching in different departments of the school. Teachers generally get low academic qualifications. Some teachers are masters, while most teachers in remote areas are just undergraduate students majoring in English in colleges. Some is weak in knowledge, while some hardworking ones have obtained an in-service master's degree. There are very few unified recruitments of doctoral graduates. The structure is such unreasonable. The university English teachers are mainly lecturers or teaching assistants. There are few associate professors neither a reasonable title structure with regards to elderly, middle-aged and youth. From the perspective of the academic structure, most of the teachers graduated from the ordinary second-tier universities, few are from professional colleges nor key universities. Many factors have led to this irrational knowledge structure of teachers, such as the lack of relevant language theory especially the depth of language knowledge, or that the teachers have difficulty in making indepth and thorough analysis and research on language, so they will have a hard time adapting themselves to the new requirements of the teaching reform of college English courses in New Era.

\section{B. The Knowledge and Ability Structure that College English Teachers Should Have}

In most local Minzu colleges, the English teachers mainly teach public English classes, whose learners are non-English majors in the school. The knowledge structure should be composed of the following parts: First is subject content 
knowledge. The important function of teacher's job is to impart knowledge. Therefore, any teacher must obtain the most basic subject content knowledge. The subject content is not only the knowledge of English language, but also the related knowledge of English culture, cross-culture, second language acquisition, curriculum, etc., because language is just a tool, a carrier of culture and various information, different languages reflect different cultures and modes of thinking. Second is subject teaching knowledge. For teachers, subject teaching knowledge is mainly related to teaching, which is used to solve "how to teach", which also means the teacher's teaching philosophy. Third is the learner's knowledge. In the process of learning, the learners will affect the teaching effect. Teachers need to understand the characteristics of learners to teach more effectively. These characteristics include the different attitudes and value orientations that learners show during their studies. Fourth is the educational situational knowledge, which refers to the comprehensive knowledge of society, country, school, family, classroom, etc. [7]

\section{The Development Measures of College English TEACHERS IN LOCAL ETHNIC COLLEGES}

\section{A. Update the Concept of Education and Teaching}

In the National Basic College English Course and Extended Course Seminar, Professor Shi Jian, former vice president of Sichuan University and doctoral tutor of Sichuan University School of Foreign Languages, pointed out that China's higher education faces a rare historical development opportunity, "building an innovative country requires plenty of innovative talents." Chinese universities should strive to "train a lot of high-quality innovative talents who are capable of independent learning, master critical thinking methods, and develop creative work habits". Only in this way can China remind in an invincible position in the future international competition. Therefore, college English teachers must update their educational and teaching concepts, focusing on the cultivation of students' innovative and intercultural learning abilities, emphasizing the breadth and depth of knowledge, stressing practical ability, and attaching importance to the reform of teaching methods.

Language is an important skill, but also a tool of thinking and a carrier of culture. Through the experiential learning, the students learn the beauty of language, improve their language skills, and then thus improve their overall humanistic quality. In English teaching, teachers should teach with thinking, converse their roles, inject humanistic spirit into the English classroom, and cultivate students' critical thinking ability. Let the students have a stable foreign language foundation and extensive cultural knowledge. Through the research learning process, the students can proactively ask questions themselves, analyze questions, solve questions, and exercise their critical thinking ability, innovative thinking ability and ability to cooperate with others. At the same time, the students will obtain new knowledge when sorting out the materials needed for the research. [8]

\section{B. College English Teachers Should Deeply Reflect on Their Teaching}

The educator Dewey believes that reflection refers to "repetitive, serious, and continuous thinking about some question". He said: "Things in thought are taken as inducements. However, thinking is not necessarily reflective. Only people who are willing to endure the puzzles with willingness and explore painstakingly, can they have reflective thinking." The alleged reflection is actually the actor's reunderstanding of the cognition of himself, the process of practical activities and related subjective perceptions. In terms of education work, it refers to the actor's re-understanding of his own educational practice activities and the potential educational concepts. As a college English teacher, not only must we prepare a good lesson, but also teach a good lesson. More importantly, we should deeply reflect on our own teaching in terms of technology, situational level and educational value after the class [9], summing up the advantages and disadvantages of our own class, the student's reaction, and what kind of thinking and value a class brings to the students. In this way, we can optimize and improve our bad teaching modes, methods and strategies, and continuously deepen our understanding of students' learning rules. To become a reflective teacher, we must have an open mind, a spirit of truth-seeking and pragmatism, and a self-critic sentiment. Learn to improve self-awareness in the process of combining self-analysis with others' evaluation. Update educational concepts and improve teaching literacy through reflection.

\section{Promote the Construction of Teaching Staff Through Team Building}

Article 17 of the National Medium- and Long-Term Education Reform and Development Plan outlines that "to build a high-quality team of college teachers should focus more on young and middle-aged teachers and innovative teams. Improve the teaching level of high school teacher, research innovation ability and social service ability. Promote interdisciplinary and inter-unit cooperation to form a high-level teaching and research \&innovation team.” [10] Only if a college English teaching team was build, can there form a cohesive force and bring in play the collective wisdom and strength of the teachers. In the College English Teacher Team Building and Interactive Development Seminar held in Beijing, Professor Wen Qiufang pointed out that the typical characteristics of the interactive team are confidence, reciprocity, equality, and collaboration. There are two reasons for conducting team building research. First, the current theory of English teaching in colleges and universities is out of practice. The second is that the current teaching reform pays less attention to the effectiveness of classroom teaching. She proposed that the teacher development research that has been implemented in middle school has taken root in the classroom and embodies the spirit of "integration of knowledge and action”, which is worthy of a reference for college English teaching research. There is a team, there is an organization. Team members should spend time to communicate with each other on teaching and research issues, to cooperate wholeheartedly, learn from each other and make progress together so that the team can really play a role. As Professor 
Wen said, "Through the close integration of key issues and specific material in teaching and research, and through the emotional and cognitive interaction, the college English teaching researchers team and the frontline teacher team can finally achieve the development goal, which is to improve the researchers' ability of combination of theory and practice and the ability of communicating with the frontline teachers, on the other hand, to improve the frontline teachers' reflective ability, teaching ability, research ability and cooperation ability.’’ [11]

\section{CONCLUSION}

The construction of teaching staff is an important part of the college development in ethnic universities. As a college English teacher, he must deeply reflect on himself, analyze his role in the college English teaching reform. Correctly position himself. Clarify his strengths and weaknesses, the opportunities and challenges he is facing as a frontline English teacher. Keep in mind the knowledge and ability structure that excellent college English teachers are supposed to obtain. Update education and teaching concepts, and deeply reflect on his teaching. Actively join in the teaching team, and seek effective development strategies with combination of his own condition, and strive to persist in practical actions, so as to be a good teacher and a guide for students, and truly play the role of serving the national region, society and students and realize his life value as college English teachers.

\section{REFERENCES}

[1] Outline of National Medium- and Long-Term Education Reform and Development Plan (2010)

[2] Liu Guiqin. Building a team of College English teachers to improve the level of talent training in colleges and universities [R]. Beijing: Foreign Language Teaching and Research Press, 2011.

[3] Shan Ronglin. Research on Metacognition Theory and Students' Autonomous Learning Ability in English[J]. Journal of Changchun Institute of Education, 2011(5): 84-68

[4] Yan Yanping. An Empirical Study on the Professional Development of College English Teachers[D]. Shanghai: PhD thesis of Shanghai International Studies University, 2011:24

[5] College English Course Teaching Requirements (2007)

[6] Yan Yanping. An Empirical Study on the Major Development of College English Teachers[D]. Shanghai: $\mathrm{PhD}$ thesis of Shanghai International Studies University, 2011:24

[7] Sun Youzhong. Understanding the development trend of college English teaching, and seeking a win-win situation for teachers and students [R]. Nanchang: Foreign Language Teaching and Research Press, 2011.

[8] Gao Zhanrong. Research on the Knowledge Structure of College English Teachers[D]. Changchun: PhD thesis of Northeast Normal University, 2011:15

[9] Shi Jian. Innovative Talents Training and College English Teaching in Colleges and Universities-Reflections on Foreign Language Teaching Reform under the New Situation [R]. Changsha: Foreign Language Teaching and Research Press, 2009.

[10] Chen Zehang. Classroom Teaching: Strategy, Evaluation and Research [R]. Beijing; Foreign Language Teaching and Research Press, 2012(7).

[11] Wen Qiufang. Theory and Practice of Interactive Team Building [R]. Beijing: Foreign Language Teaching and Research Press, 2011. 